\title{
Rise and Fall of Microfinance in India: The Andhra Pradesh Crisis in Perspective ${ }^{1}$
}

\author{
Philip Mader \\ Max Planck Institute for the Study of Societies, Cologne, Germany
}

\section{Indian microfinance institutions pursued reckless growth at all costs and ignored all warnings in a particular environment inherited from the past. \\ Their business model was built on shaky foundations, until a blundering Andhra government stepped in.}

$7 \mathrm{c}$ he crisis of microfinance which erupted in 2010 in Andhra Pradesh has complex causes rooted in Indian history.

\section{Introduction}

The microfinance crisis which erupted in the Indian state of Andhra Pradesh in October 2010 is the deepest crisis event in microfinance so far. It has widely, but falsely, been perceived as a sudden event triggered by acts of the Andhra government. Putting the rise of Indian microfinance into perspective reveals longer-term causal processes driving the creation of the massive debt bubble in Andhra Pradesh which precipitated the crisis of Indian microfinance. This article provides an analytical narrative of the rise and fall of Indian microfinance, showing how the crisis was not a product of wanton political machinations, but was spawned by forces within the microfinance industry itself. These, in turn, footed on longer historical lineages of credit as a tool of social policy in India, compounded by the neoliberal reforms of the 1990s, which generated an ideal breeding ground for overindebtedness among poor populations increasingly made dependent upon debt for survival.

\section{An unstable base}

India was a late starter in microfinance, compared with its smaller neighbor Bangladesh, with which it shares the history of cooperative credit introduced by the British Empire (Turnell, 2005; Wolff, 1910, pp. 514-544). This cooperative credit formed the beginning of the region's century-long experimentation with credit as an instrument of social policy. After independence, India's state-driven industrialization policies at first did not emphasize rural credit, but when alliances in the Indian ruling classes shifted, in 1969 the majority of India's largest commercial banks were nationalized and the state adopted a new lending focus on rural areas

${ }^{1}$ JEL classification codes: O160, P160. 
and the agricultural sector. Banks' share in rural credit rose from $3 \%$ to $15 \%$, which created growth of non-agricultural output in rural areas and an expansion of small business activity (Burgess and Pande, 2003). This also led to a collapse in the informal credit extended by moneylenders, traders, and landlords, whose shares in household debt fell by more than half in the 1970s, while the share of household debt to formal institutions doubled (Shah et al., 2007).

A large portion of lending to poor people in India in the 1970s and 1980s also came from the state through the Integrated Rural Development Program (IRDP), whose subsidized credit for farming improvements and livelihood diversification projects was not an operational success, but left a legacy of rural lending as a major tool in the development portfolio (Taylor, 2011, pp. 486487). Many poorer households in India had their first experiences with formal-sector debt through these initiatives. In the same era, women also organized their own credit projects; for instance, SEWA (Self-Employed Women's Association of India) was formed in 1972 as a trade union which organized women into cooperatives, offering banking services (among other things) and, two years later, the movement founded its own SEWA Bank (Datta, 2003).

Based on this experience, microfinance began in India with state-sponsored Self-Help Group (SHG) lending models increasingly fulfilling formal lending to the poor from the late 1980s onwards. These SHGs started in 1984 when the cooperatives managed by Myrada, a parastatal agency working particularly in the South of India, collapsed and many members began organizing their own groups for savings accumulation. Myrada and NABARD (the National Bank for Agriculture and Rural Development) together trained and expanded these groups, linking them to banks; this bank linkage was mainstreamed by the Reserve Bank of India (RBI) beginning in 1996 (Aiyar et al., 2007, p. 111). The program had garnered support from the World Bank by the turn of the millennium, and still continues to be financially supported by the state and the World Bank - it now includes 11 million women in Andhra Pradesh (AP) alone (Nair, 2005; World Bank, 2010). According to NABARD (2012, pp. 4-6), there are now almost 8 million SHGs serving 103 million households in India, of which 4.4 million SHGs have loans directly from banks.

\section{Politics of banking on poverty}

The rapid rise of microfinance - to be precise, loans disbursed by specialized microfinance institutions (MFIs) - in India began in the late 1990s, continuing the tradition of credit as a social policy. The liberalization of India's economy and its financial sector after 1991 changed the composition of lending once again, with credit from the private sector rising in favor, even as the state remained a driving force in the background.

The first MFI entrants emulating or adapting the internationally widespread Grameen model in India were NGOs like BASIX, who were promoted by the Reserve Bank of India (RBI) and NABARD, hoping to achieve lower transaction costs than state-sponsored or SHG lending to the poor (Fernandez, 2009; Taylor, 2011). As Taylor (2011) argues persuasively, key causes for the expansion of credit from these MFIs (and subsequent collapse) can be found in the persistent crisis of India's vast agricultural sector, which still employs more than half the country's labor force, but generates only $18.5 \%$ of income (CIA World Factbook, 2011). The Indian farmers' crisis lies, to a large extent, at the root of the country's social crisis, which became a driving force in its microfinance sector's rise.

Though India was late in adopting the standard microfinance model, which existed since the 1970s in Bangladesh, it fell onto fertile ground among poor populations well-accustomed to and experienced in the management of debt. Under the neoliberal liberalization and retrenchment agenda since the early 1990s, these populations' livelihoods became increasingly squeezed, making them more dependent upon debt for survival. Taylor (2011) shows how the percentage of rural households in 
debt rose all over India since the 1980s, but most dramatically in AP, where $82 \%$ of farmer households were indebted in 2003, compared with 48.6\% Indian average. As Taylor (2011, p. 3) explains, within the expansion of microfinance in the late 1990s:

Andhra Pradesh became a magnet for microfinance start-ups and witnessed a proliferation of loans from private MFIs. [. . .] The ability of MFIs to scale up their operations in Andhra Pradesh rests in part upon the institutional infrastructure and culture of formal credit put in place through the social and development banking schemes of the 1970s and 1980s, alongside the expansion of the self-help group (SHG) model under the auspices of the state in the 1990s and 2000s.

Young (2010) argues that the microfinance explosion in Andhra Pradesh was predicated on this state engaging in some of the most ambitious and enthusiastic neoliberal programming in all of India; particularly under Chief Minister Chandrababu Naidu, whose agenda was supported by IMF structural adjustment lending. ${ }^{2}$ One of AP's reform focuses lay on scaling back subsidized rural credit, which MFIs happily stepped in to replace. The state in turn supported this microfinance expansion (politically and logistically) since it allowed retrenchment of spending on social programs.

This created particularly acute problems in rural areas, considered Naidu's major support base, due to declining investments in agriculture. The solution that Naidu sought to this problem was through microfinance. With funding and technical support from the World Bank, he dramatically expanded the state's "Self Help Group" scheme on the back of a major public relations campaign. (Young, 2010, p. 615)

Sensing an immense opportunity for lending, commercial microfinance providers entered the market, capitalizing

${ }^{2} \mathrm{AP}$ was applauded by The Economist as "the state that would reform India" (The Economist, 2000). on the large number of available borrowers experienced in managing credit through the SHGs. SHGs complemented MFIs; by the early 2000s, more than half of all SHGs in India were concentrated in AP, offering MFIs a pool of experienced borrower groups on which they could "piggyback" their lending. ${ }^{3}$ The World Bank, meanwhile, continued supporting the expansion of SHG-bank linkages via financial and logistical backing.

\section{Need, not opportunity}

Four interconnected processes increasingly squeezed Indian cultivators since the mid-1990s, generating a crisis of social reproduction in the semi-arid areas of India (particularly AP). First, population pressures forced many farmers to work ever-smaller and more marginal plots of land. Second, increasing cultivation of non-food crops made farmers more dependent on volatile markets for inputs as well as outputs. Third, a "privatization of risks" was caused by the breakdown of patronage relationships, retrenchment of social welfare, and destruction of common resources. Fourth, farmers faced an increasingly degraded ecological environment and volatile climate patterns. These factors, not new opportunities for development, drove many borrowers into the hands of microfinance institutions (Taylor, 2011).

Taylor (2011, p. 13) thus notes how it was precisely "at the end of the 2003-6 drought that private microfinance began its rapid ascent, and the most recent crisis follows another period of sustained drought in 2009." Given these circumstances, microfinance served

\section{simply to prop up a rural population that has been made surplus to the needs of capital accumulation in neoliberal India [. . . and it] facilitated a cycle of indebtedness in which households began to use multiple sources of debt - including microfinance institutions, but also other informal lenders — to attempt to}

\footnotetext{
${ }^{3}$ Piggybacking can be defined as lending to existing borrower groups, instead of doing the work of forming new ones. Later, a common term would become "poaching."
} 
overcome barriers to their social reproduction. (Taylor, 2011, pp. 17-18)

But the growth of the microfinance industry could not resolve the socio-economic tensions built into India's economy of "poverty amid plenty" (Kohli, 2012); it merely accumulated them into the credit system which served as a temporary and unsustainable palliative.

\section{A troubled rise}

The rapid growth of MFI microfinance in India from the late 1990s until 2005 was borrowing-driven at two levels. First, the legal forms adopted by most MFIs - either NGO or Non-Banking Financial Company (NBFC) — did not legally permit them to collect savings from clients, so that their business models focused on lending. Second, since equity capital was not yet forthcoming significantly, nearly all capital had to be borrowed from larger domestic financial institutions or donors abroad. In 2004, there were 87 MFIs with a portfolio of US\$249 million, which rose to 93 MFIs and US $\$ 463$ million by 2005. ${ }^{4}$

\section{The Krishna crisis}

A frenzy of lending (by MFIs, and by banks to MFIs) was already underway when a first stark warning came in 2006 from the Krishna District. After a popular demonstration by borrowers demanding back their house title deeds, which had been seized as collateral, turned violent and, consequently, more than 50 MFI offices of Spandana Sphoorty and SHARE Microfin ${ }^{5}$ were temporarily closed by the government, the government of AP ordered an inquiry into allegations of MFIs pushing reportedly up to

\footnotetext{
${ }^{4}$ The source for these figures is Mixmarket, August 20, 2012. MFIs report voluntarily to Mixmarket, so not all activity is registered, and data quality and transparency remain fairly poor, but these figures are still commonly considered the most reliable estimates of country-level microfinance data.

${ }^{5}$ In 2010, these organizations were, respectively, the second and fourth largest MFIs in India.
}

200 borrowers into committing suicide. Repayment rates went down to between $10 \%$ and $20 \%$ for several months in the district (Ghate, 2006, pp. 61-66, 2007a; Sharma, 2006).

In 2006 (just as again in 2010), the microfinance industry denied responsibility for any wrongdoings, and accused the government of protecting and promoting its own "Velugu" SHG lending program, claiming the state's intervention was an act of predation on civil society by politicians (Intellecap, 2010; Shylendra, 2006; Wright and Sharma, 2010). Yet industry dissenters like Ghate (2007b), author of the 2007 and 2008 Indian microfinance State of the Sector reports, argued that competition between state and MFIs was only an "enabling" cause of the crisis, while in fact the "underlying" longer-term causes were MFIs' "quest for numbers" (viz. growth), their intransparent interest charges, questionable collection practices, the weaknesses of the SHG model and, above all, MFIs' inadequate perception of risks: “The most important enabling (or contextual) cause was the nearsaturation of coastal Andhra with microfinance" (Ghate, 2006, p. 63); see also Arunachalam (2011, pp. 42-60).

\section{From loan to investment}

Commercial banks who lent to MFIs lost money in the Krishna crisis, diminishing their willingness to fund MFIs. This led to a brief lull in nationwide loan portfolio growth. But, as Arunachalam shows, equity investors soon eagerly stepped in. After Krishna, more capital flowed into Indian MFIs as long-term investments, rather than shorter-term bank loans. The average debt/equity ratio of Indian MFIs declined from 11.05 in 2005 to 4.69 in 2009. This would fall further to 2.41 by $2011-12$, with the previously better-leveraged AP-focused $\mathrm{MFIs}^{6}$ having a ratio of only 1.26 after the crisis (MFIN, 2012, p. 22).

Between 2005 and 2010, many NGOs transformed into shareholder-owned MFIs, pursuing growth by

${ }^{6}$ Defined by MFIN as those with more than $20 \%$ portfolio in AP. 
building a capital base and subsequently leveraging more debt. Before March 2006, according to Arunachalam's (2011, pp. 64-95) data, a mere US\$6.3 million was invested in Indian microfinance, but this grew to US\$26.2 million in 2007 and US\$118.3 million in 2008. The 25-month period from April 2008 to July 2010 (up to the IPO of SKS Microfinance) finally saw an inflow of US\$528.6 million, which reflected a veritable microfinance investment mania. This equity infusion drove a rapid growth in lending, mainly among six "equity leader" ${ }^{7}$ MFIs who attracted $80 \%$ of investments, with the rest going to 22 "equity followers." Private capital from India and abroad in search of extraordinary returns fuelled a vast lending machine commanded by the six "leaders," whose portfolios grew at a compound annual growth rate of $89 \%$, allowing them alone to add US $\$ 2.7$ billion to their loan portfolios between March 2006 and March 2010. But, on the eve of the crisis, the September 2010 issue of MicroBanking Bulletin identified a herd of highly ambitious smaller MFIs ("young turks"), still making losses but rapidly becoming profitable, attracting investments even faster than the sector leaders or the middle ranks (Parameshwar et al., 2010). Evidently, microfinance investors had become progressively less risk-averse, keener than ever to spot rising stars in Indian microfinance, when the crisis hit.

Among the ranks of investors piling into Indian microfinance, there were international players like Sequoia Capital, an American venture capital fund who supplied $23.6 \%$ of the equity capital of SKS Microfinance with an explicit aim to "exit" with its profits through a share issue on the stock market (Chadha, 2009; Nath, 2009). But equity growth was not all: the largest MFIs also engaged in increasingly sophisticated financial transactions such as a US\$42.6 million microloan securitization deal between SKS Microfinance and ICICI Bank (India Microfinance, 2009).

Their strong capitalization permitted MFIs to shoulder ever-larger loans from Indian banks, who were eager

${ }^{7}$ Arunachalam deliberately leaves the six leaders unnamed. to lend to them to meet state-mandated "priority sector" lending requirements - a minimum $40 \%$ of credit - because microfinance generated higher and more reliable returns than other "priority sectors" (Rediff Business, 2004; Reserve Bank of India, 2011). ${ }^{8}$ In this way, the Indian regulation regime encouraged the microfinance explosion by making borrowed capital more amply and cheaply available for MFIs, while the government abdicated responsibility for regulating the burgeoning sector, since the actors were not banks, but NBFCs and NGOs. ${ }^{9}$ Large Indian banks, in any case, took the well-capitalized and fully commercialized MFIs to be safe bets, and increased their lending to MFIs more than sevenfold between 2006/7 and 2009/10, while regulators looked on.

This immense growth along all dimensions vastly overstretched MFIs' internal systems, and they cut corners everywhere, particularly in the client acquisition process. External "agents" were apparently widely used to recruit new clients (Arunachalam, 2011, pp. 308-329). From April 2008 to March 2010, each of the six "equity leader" MFIs added 2,389 new active clients, or 479 new joint loan groups (JLGs) on average every day (Arunachalam, 2011, p. 74) - an immense logistical task, to say the least — so that by March 2010 statistically 35.9\% of all households in AP had an MFI loan. ${ }^{10}$ The fact that the growth witnessed in AP was impossible on a "know your

\footnotetext{
${ }^{8}$ The interesting question arises as to why banks, who also could lend directly to SHGs, would choose to lend so copiously to MFIs. The most likely explanation is volume and externalization of costs. In the SHG-bank linkage program, banks lent at 9-12\% per annum (Reddy et al., year unknown, p. 9), approximately the same rates they charged to MFIs, which were 9.9-12.3\% (Parameshwar et al., 2010). By lending to MFIs, Indian banks could disburse larger lump sums, needing only to assess the performance of the MFI and deal with one MFI, rather than multitudes of individual SHGs. ${ }^{9}$ The reasons for the failure to regulate Indian microfinance cannot be dealt with sufficiently here. Suffice it to say that it is mysterious how an array of successive regulatory efforts over many years could all fail.

${ }^{10} \mathrm{AP}$ was followed by Karnataka with $32.2 \%$, Tamil Nadu (19.8\%), and Orissa (19.4\%) according to the Centre for Microfinance (Champatiray et al., 2012, p. 34).
} 
customer" basis is illuminated by SKS Microfinance - the sector leader - adding 4.17 million clients from April 2008 to March 2010, pushing its loans to 488 loans per loan officer by 2009 (as reported to the database Mixmarket). Also in the same period, the average borrower's debt balance (toward each MFI) more than doubled; a debt accumulation compounded by multiple borrowing.

The Krishna crisis story meanwhile repeated itself in smaller forms in other parts of Southern India (Nizamabad (AP), Kolar (Karnataka), and Idukki (Kerala)) (Sriram, 2010). These events cannot be dealt with in depth here, and in any case they were disregarded by investors and policy-makers, who were dazzled by wildly optimistic and unsubstantiated growth predictions. An October 2007 report, for instance, estimated total demand for microcredit in India to be more than US $\$ 50$ billion, at a time when the whole sector was lending only US $\$ 1.39$ billion. It predicted US $\$ 6.27$ billion to 48.7 million borrowers by 2012 (Intellecap, 2007). Indian MFIs were treated as global leaders, with a 2008 ranking of the top 50 MFIs worldwide - described as "well rounded, leading microfinance service providers" - naming seven Indian MFIs. SKS Microfinance was listed second (Mixmarket, 2008). ${ }^{11}$

\section{Warnings ignored}

Thus, in the late 2000s, Indian microfinance was "hot." Particularly its large MFIs were among the fastest-growing in the world (in absolute numbers), triumphantly using their ample capital base to outcompete or swallow smaller MFIs. As Vikram Akula of SKS told a newspaper in late 2008:

\section{In the current environment, capital is flowing to quality and this is affecting the small and medium MFIs [. . .] Banks are lending only to large MFIs. We are in a strong position. We are holding discussions}

\footnotetext{
${ }^{11}$ A Forbes ranking, using different criteria, also listed seven Indian MFIs under the top 50, but in a different order, with Bandhan coming global second (Swibe, 2007).
}

with MFIs who are facing strain and helping them by taking over their clients (cited in Bhoir, 2008)

A most hubristic generosity.

The immense loan factory's lynchpin was Andhra Pradesh, which accounted for just under 30\% of India's portfolio in 2009 , despite being home to only $7 \%$ of the population (Srinivasan, 2009). Although critical voices had questioned the soundness of the growth pattern and aspirations starting from the mid-2000s, the evident overvaluation and overcapitalization bubble was ignored by players and regulators alike. The 2010 crisis was what Srinivasan, author of several State of the Sector reports, called a "crisis by invitation":

\section{The microfinance sector had been given enough warning signals. (Srinivasan, 2010)}

Warnings included Chowdri (2011) of the global microfinance network ACCION in June 2009 remarking how the industry only ever blamed politicians for its recurring troubles and crises, but failed to appreciate home-made causes, including "insufficient systems for tracking indebtedness, unfettered competition, irrational growth expectations, and little analysis and understanding of the client's ability to repay." An omen from another angle was reporting by the Wall Street Journal about clients perpetually over their heads in debt, driven by group pressure to attempt suicide (Gokhale, 2009b). Traditional moneylenders were not being displaced by MFIs, but rather were thriving thanks to them, effectively becoming part of the business model as moneylender loans were increasingly taken to repay MFIs (Gokhale, 2009a). Rozas (2009), a consultant with US mortgage market experience, asked: "is there a microfinance bubble in South Asia?”, concluding that Andhra Pradesh was already 6\% over its capacity by 2008. In February 2010, the World Bank's in-house microfinance promotion agency CGAP voiced concerns that Indian microfinance was overstretching its capacities and losing credit "discipline" (Chen et al., 2010, p. 12). On the eve of the crisis, even the ever- 
upbeat MicroBanking Bulletin noted that portfolio quality was seeing "deterioration in pockets," but maintained it was "healthy overall" (Parameshwar et al., 2010, p. 6). And finally, industry insider M.S. Sriram presaged in May 2010:

If the MFI gives the sense to the borrower that it is unscrupulous, the borrower will take the MFI for a ride sooner or later! The day they reach a tipping point where they think enough is enough, they will default. Neither coercion nor any group mechanism will work. It will not work because we would have already put them into a debt trap and this is the only response they have. (Sriram, 2010)

These warnings and others, which almost precisely foreshadowed what was to come, were all disregarded and — after the crisis — comfortably forgotten.

\section{The Fall}

In October 2010, the Chennai-based Centre for Micro Finance noted with alarm that in Andhra Pradesh " $[\mathrm{t}] \mathrm{he}$ overall rate of indebtedness is extremely high" (Johnson and Meka, 2010, p. 19). It reported clients borrowing from a large variety of formal and informal sources, though vastly more from informal sources, and that $84 \%$ of households had two or more loans, while $58 \%$ even had four or more loans. Regardless of who originated the majority of these loans - MFIs, SHGs, or moneylenders - this expansion was anything but sustainable. The MFI sector's loan portfolio had grown between $64 \%$ and $98 \%$ each year, making it the second largest in the world by 2010 .

Indian microfinance was also immensely profitable. The sector's average return on equity (RoE) lay at $27.5 \%$ in 2008, and 25.0\% in 2009; the largest 10 MFIs meanwhile were even earning on average $37.8 \%$ and $35.2 \%{ }^{12}$

\footnotetext{
${ }^{12}$ Source: Mixmarket, as of 09.15.2011, weighted average. Weighted averages for the 10 largest MFIs in India in 2008 and 2009 are weighted by loan portfolio; own calculations using Mixmarket data.
}

in 2008 and 2009, respectively. ${ }^{13}$ Investments in Indian microfinance enjoyed a reputation as being virtually riskfree thanks to the sector's widely touted loan repayment rate of over $99 \%$.

\section{SKS}

On the heels of this growth spurt and profit mela, SKS Microfinance went "public," culminating the Indian microfinance bubble in summer 2010 with the first Indian microfinance IPO. ${ }^{14}$ SKS had been started in Andhra Pradesh in 1997 by Indian-American "social entrepreneur" Vikram Akula as a non-profit venture, but this NGO transformed into an NBFC in 2005 and, by 2007, had become India's largest MFI. In March 2010, SKS had announced its plan to access the stock market (Maggio, 2010), and the IPO went forward at the end of July, hailed as a massive financial success. Investors oversubscribed more than 13 times, and at approximately US $\$ 1.5$ billion, the company was valued at nearly 40 times its 2010 earnings. The IPO raised US $\$ 358$ million and share prices climbed $11 \%$ on day one (The Economic Times, 2010a), and continued to rise over the following six weeks.

But the IPO occurred under controversial conditions. Just a month previously, Seattle-based NGO Unitus had announced (to international puzzlement) that it was selling all its shares in SKS for US\$70 to 80 million, and also exiting microfinance altogether, laying off over 40 employees (Rajshekhar and Grenny, 2010). Unitus' board members themselves had invested in SKS shares and stood to profit from the IPO (Strom and Bajaj, 2010). ${ }^{15}$ The fact that Quantum Hedge Fund (founded by George Soros) was allowed into SKS as an investor mere days before the IPO, paying only roughly two-thirds of the

\footnotetext{
${ }^{13}$ Comparing these figures to others clarifies how lucrative Indian MFIs were. For instance, the RoE of US firms in 2008 was $15.2 \%$, and merely $9.9 \%$ in 2009 , while for US financial services it was $7.2 \%$ and even minus $69.0 \%$, respectively (Damodaran, 2011).

${ }^{14} \mathrm{IPO}=$ initial public offering; stock market share issue.

${ }^{15}$ The potential conflict of interest of these "non-profit" NGO leaders was never paid sufficient attention to.
} 


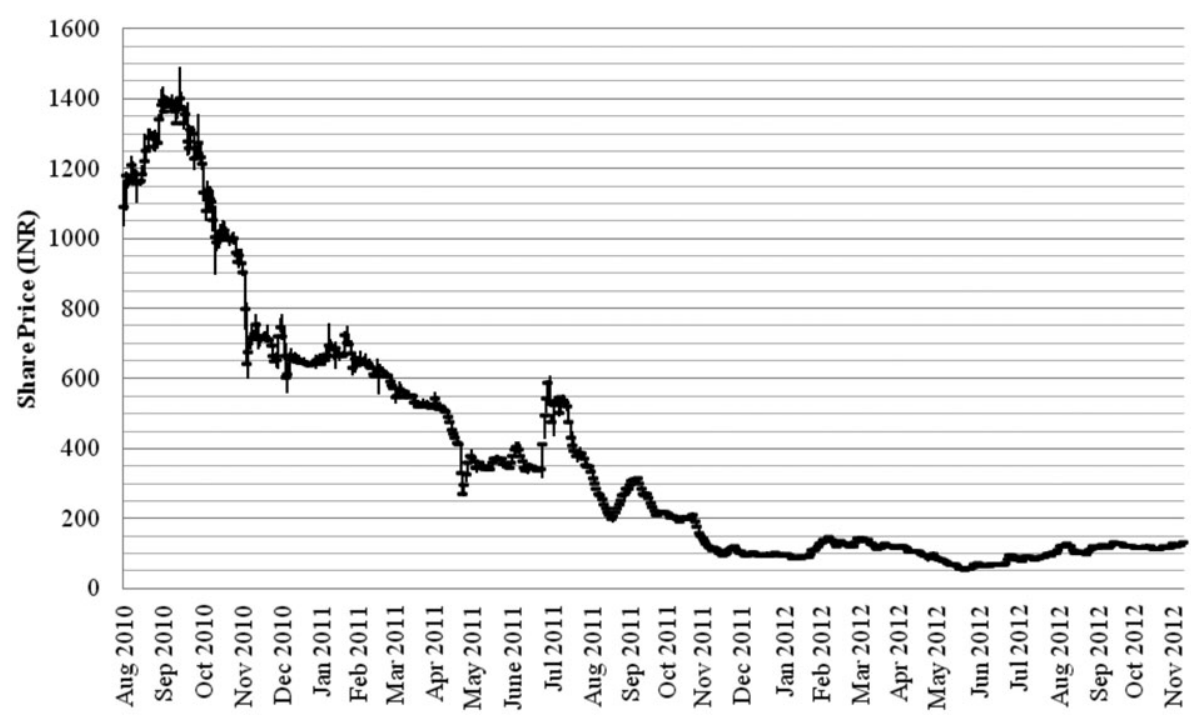

Figure 1. Evolution of SKS Microfinance share price since IPO.

IPO price, was eyed with suspicion (India Microfinance, 2010). Already, the near-majority ownership of SKS by only three large institutional investors and one billionaire - Sequoia Capital (21.8\%), Kismet Capital (5.7\%), Sandstone (12.9\%), and Vinod Khosla (6.6\%), in May 2010 - had sustained the impression of a club of rich investors seeking to cash in on poor borrowers.

Another $16.1 \%$ of SKS shares were held by SKS Mutual Benefit Trusts (MBTs), an odd collection of village-level women's groups representing around 6.8 million women, with unclear control and sales rights for their shares (Kumar and Rozas, 2010). These MBTs were flaunted as evidence of SKS's pro-poor orientation, though Ghosh (2012, p. 9) notes their function as a "legal innovation" for channeling "developmental" donor funds, not intended for profit-making, into the capital pool of forprofit MFIs. The impression of a boon for a small elite was widespread, particularly since founder Akula sold part of his own shares for nearly US $\$ 13$ million earlier in 2010. He thus earned more than any other banker in India that year, leaving him still with around US\$55 million in shares (Bellman, 2010; Strom and Bajaj, 2010). In a sinister twist, according to Arunachalam's (2011, pp.
93-94) examination of the balance sheets, Akula only owned these shares thanks to borrowing roughly US $\$ 350,000$ from SKS to buy them at INR 10 per share, a discount of nearly $99 \%$ against the IPO price. See Figure 1.

Naturally, the system of Indian microfinance was more comprehensive than SKS's activities alone, but SKS iconically stood for the overall trajectory and aspirations. It seemed to prove that the dream of transforming an NGO into a profit-seeking company, achieving growth and profitability through equity investments, finding ultimate success on the stock market, all crowned with the saintly image of assisting the poor, could come true. SKS raised the same ethical questions as the IPO of Compartamos had in Mexico three years earlier. ${ }^{16}$ At the time of

\footnotetext{
${ }^{16}$ The issues around Compartamos related to whether the IPO had served to channel donor funds into private pockets; whether high interest rates had whittled away impacts on the poor; the ethics of making the poor pay for private profits (or at what point microlending becomes loan sharking); and the extent to which the IPO was a boon mainly for foreign, rather than domestic, investors (Ashta and Bush, 2008; Ashta and Hudon, 2012).
} 
SKS's IPO, the media were reporting the plans of a number of Indian MFIs to "go public" soon, including Spandana Sphoorty and SHARE Microfin (the number two and three players in 2009), and large-scale mergers among other significant MFIs were being discussed (see, for example, Acharya, 2010; Nath, 2009).

\section{The crash}

In late September and October 2010, accounts of borrowers in Andhra Pradesh committing suicide accumulated (Sify News, 2010; Times of India, 2010b,c). Arunachalam (2011) notes that rising default rates and grievances about coercive repayment techniques were already tangible at field level in August 2010. ${ }^{17}$ As early as June 2010, there were warnings about actual default rates being far higher than reported, but MFIs hid them by "rolling over" loans, replacing older non-performing loans with new ones registered as "performing" (David, 2010).

When, on October 14th, the State Rural Development Minister of Andhra Pradesh announced that an Ordinance would be passed to protect borrowers from "harassment" by MFI agents, his announcement did not come out of the blue, but against a backdrop of protests by microfinance borrowers as well as alarming reports in local newspapers of rapidly increasing violence (Nayar et al., 2010). This violence was between borrowers, by MFIs against borrowers, and by borrowers against MFIs. Allegations included instances of kidnapping children and the forced prostitution of young girls to coerce their parents into repayment, as well as abundant reports of MFIs' agents pressing clients to commit suicide so that life insurances could repay the loans (Nagaraju, 2010; Times of India, 2010a).

The AP government's Ordinance was passed and released on Friday October 15th, citing 30 suicides in 45 days as the reason for protecting borrowers from MFIs

\footnotetext{
${ }^{17}$ To gain ultimate clarity about the extent of problems known before mid-October 2010, MFIs would have to open their books and show daily/weekly loan collections data, which none of them have done.
}

and their agents (The Economic Times, 2010b; The Hindu, 2010). ${ }^{18}$ The Ordinance asserted that MFIs were responsible for "usurious interest rates and coercive means of recovery resulting in [SHGs'] impoverishment $\&$ in some cases leading to suicides" (Government of Andhra Pradesh, 2010). It required MFIs to state their interest rates clearly and register all recovery personnel in each district they operated in. It prohibited the recovery of loans and granting of new loans until such registration was completed. The Ordinance further forbade the collection of collateral on loans, the charging of interest "in excess of the principal amount" (a meaninglessly high limit), and the issuing of multiple loans to the same borrower group. It furthermore specified that MFIs should "not deploy any agents for recovery nor shall use any other coercive action," threatening to imprison the managers in case of breach. The Ordinance thus prohibited many actions that MFIs previously considered perfectly normal, like door-to-door collections or pressuring borrowers by following them around, but also the ones that were officially claimed to be aberrations, like systematic intimidation or the use of external agents.

Only a few (temporary) arrests were ever made on the basis of this Ordinance, and only at lower organizational levels. But microfinance in AP came to an effective halt, as Vijay Mahajan, President of the Microfinance Institutions Network (MFIN) representing 44 MFIs, protested on October 19th: "Over 25,000 staff is sitting at home or at offices. Repayment is not taking place. If it continues for 60 to 90 days, it would lead to repayment holiday. And that would trigger mass defaults" (NDTV Profit, 2010). MFIN submitted a petition to the Andhra Pradesh High Court to have the entire Ordinance quashed, yet the Court temporarily upheld the Ordinance's requirement for MFI registration on October 20th, permitting however loan collections and lending to continue (Sudhir, 2010).

\footnotetext{
${ }^{18}$ It was misleadingly termed as an Ordinance to protect SHG women's groups, but in fact the Ordinance extended beyond women and SHGs to all microfinance borrowers.
} 
The Ordinance's effect of legally halting microfinance, on which MFIs blamed their woes, thus lasted only five days.

\section{In denial}

For the microfinance industry, the Ordinance was nonetheless a catastrophe because of the damage to its saintly reputation as much as the signal it sent to investors and lenders that borrowers would not be forced to repay their loans at any cost. Borrowers' rights to protection from their ostensible savior were anathema to the microfinance industry, which reacted by lowering interest rates, denying responsibility, and denouncing the government's motives.

After less than a week, SKS and other MFIs announced their decision to cut interest rates; but this move backfired because it drew attention to what were publicly perceived as very high interest rates, at reportedly between $24 \%$ and $28 \%$ annually (in fact, up to $60 \%$ ). ${ }^{19}$ The cut also revealed that lower interest rates had been possible, but MFIs were unwilling to grant them.

In terms of denying responsibility, think-tanks like Hyderabad-based Intellecap were quick to challenge the connection between microfinance operations and suicides

\footnotetext{
${ }^{19} 24-28 \%$ was the figure reported by MFIs at the time. However, newspapers reported in reality interest rates went up to 59\% (The Hindu Business Line, 2010), and rates divulged under the Ordinance's new transparency requirement were up to $60.5 \%$ APR (Shridhar, 2010). A sample survey conducted by the Small Industries Development Bank of India in December 2010 confirmed that the median APR (including all costs) was $32.33 \%$, and some loans cost as much as $60.27 \%$ (SIDBI, 2011, p. 12). The Malegam committee, which investigated the microfinance industry in 2011 under the auspices of the RBI, found: "For the larger MFIs the effective rate [...] ranged between $31.02 \%$ and $50.53 \%$ with an average of $36.79 \%$. For the smaller MFIs the average was 28.73\%." The committee also reported on rampant interest rate intransparencies and tricks, for instance that "some MFIs recover a security deposit in cash from the borrowers [which] amounts to charging interest on the gross value of the loan when only the net amount is disbursed. The practice of security deposit, therefore, distorts the interest rate structure and should be discontinued" (Malegam, 2011, pp. 11, 15).
}

(Intellecap, 2010), but when the Society for the Elimination of Rural Poverty (SERP) published its report detailing 54 suicide cases and the specific MFIs implicated (SERP, 2010), the fact that a number of clients had taken their lives due to debts could no longer be denied. MFI spokespeople then placed blame on other lenders for overindebting their clients, claiming that a few "fly-by-night" operators or "rogue MFIs" were responsible for abuses (see, for instance, Bamzai, 2010; Shankaran, 2010). But in fact, the industry never called out any perpetrators and, as $\mathrm{BBC}$ reporters discovered, industry insiders privately acknowledged wrongdoings, yet refused to go on record (Morris, 2011). Ashta et al.'s (2011) subsequent investigation across different Indian states found positive but nonsignificant correlations between MFI microfinance penetration and suicide rates, as well as stronger significant correlations between SHG penetration and suicides. Their comparison across different countries suggested that, globally, microfinance penetration was a positively associated factor with male, but not female, suicide (significant to $90 \%){ }^{20}$

Finally, in an attempt to arouse international sympathy, MFIs denounced the government's act as politically self-serving. The Ordinance was not about client protection, they claimed, but a "turf war" initiated by the state to protect its inevitably inferior SHG program from more advanced MFI competition (Intellecap, 2010). The crisis therefore was "a Battle to Monopolize the Poor" (Rai, 2010). Investors meanwhile couched their complaints in ostentatious concerns about the poor being "denied their fundamental right to make their own financing choices"; one of the funds asserted that the "AP Act that eliminates law-abiding private sector participants in the market and directly benefits the government-backed provider is unfair

\footnotetext{
${ }^{20}$ The authors did not imply causation, but noted: "Suicides may perhaps be just the tip of the iceberg. Debt produces stress which could also lead to other diseases and, in the absence of availability of appropriate medicines at prices affordable by the poor, may lead to deaths which are not labeled as suicides" (Ashta et al., 2011, p. 24).
} 
at best and illegal at worst. [. . .] The AP Act does not try to hide its anti-competitive aims" (Legatum Ventures, 2011, pp. 6, 10). This strategy of politicizing the Ordinance offered international practitioners and publics a new culprit to blame, the AP government, and directed their attention away from the overindebtedness problems of the MFI model. As any argument based on intention, it was practically impossible to disprove: whatever the AP government did, it was always for politically self-serving reasons. Moreover, most usefully, this strategy presented MFIs and their clients as victims of political conspiracy, in need of help to rein in the unruly and cruel Andhra government.

\section{Aftermath}

Lessons from the crisis could shape the future of microfinance around the world, affecting the lives of millions of people. But, while Indian MFIs are now shrinking, the industry remains in denial mode. As a consultant generally sympathetic to the industry, Daniel Rozas notes:

There is at SKS and probably at most Andhra MFIs a sense of victimhood. Such is the extent of their focus on the wrongs committed by the AP government that they fail to see - indeed, they actively try not to see - their own culpability. For there is little doubt that there were instances of severe harassment by the MFIs that may have contributed to borrower suicides. (Rozas, 2012)

When the industry body MFIN hired the Hyderabadbased company Glocal to independently investigate each suicide case individually, Glocal confirmed strong links between the acts of MFI staff and the borrower suicides. But the report was never published, and MFIN kept all details under seal. MFIs never admitted to any fault or paid any compensation (Rozas, 2012).

The efforts of the Indian microfinance industry to appeal for sympathy internationally and regulatory relief domestically, while continuing to operate the same business model as before, succeeded in arousing international attention yet have produced little practical effect. Indian microfinance has not collapsed entirely, but is contracting. The dramatic early prognoses of doom have been replaced by somber forecasts of a prolonged period of restructuring. As industry body MFIN predicted in fall 2011: "[f] or the first time in the history of Indian microfinance, the industry is likely to witness negative growth this year. At an aggregate level, the decline may be in the range of 20-40 per cent by March 31, 2012" (The Hindu Business Line, 2011).

Data for the Indian microfinance sector overall in 2012 is not available yet, but the Andhra crisis has clearly decimated the sector, with the overall loan portfolio shrinking from US\$5.4 in 2010 to 4.3 billion in 2011, and the number of borrowers declining 32.5 to 26.4 million. As of mid-2012, the loan portfolios of each of the six largest MFIs - who accounted for nearly twothirds of nationwide loans in 2009 - had shrunk substantially, but to different extents: SKS Microfinance's loans stood at a mere $20.7 \%$ of their peak volume; Spandana Sphoorty at 67.5\%; Bandhan 90.4\%; SHARE Microfin 57.0\%; AML (Asmitha) 76.7\%; and BASIX only $15.5 \%$ (see Figure 2). ${ }^{21}$ Bandhan and BASIX are the only MFIs in this group with less than 20\% loan exposure to the state of Andhra Pradesh (MFIN, 2012). The survival of key players is anything but certain.

Perhaps the clearest picture of the crisis' effects on the industry may be gained from the increase in loan delinquency (see Figure 3). "Portfolio at risk" (PaR), measured in payment delays of 30 and 90 days, is the

\footnotetext{
${ }^{21}$ Source: Mixmarket, November 20, 2012. All figures as of September 2012, except SHARE (June 2012). The dramatic decline in BASIX's loan portfolio is at least partly reflective of a change in business model away from lending (Harper et al., 2011).

22 "Peak" value is the highest quarterly figure ever reported to Mixmarket; all others except 2012 are year-end figures. Spandana's reported peak was in 2009.
} 


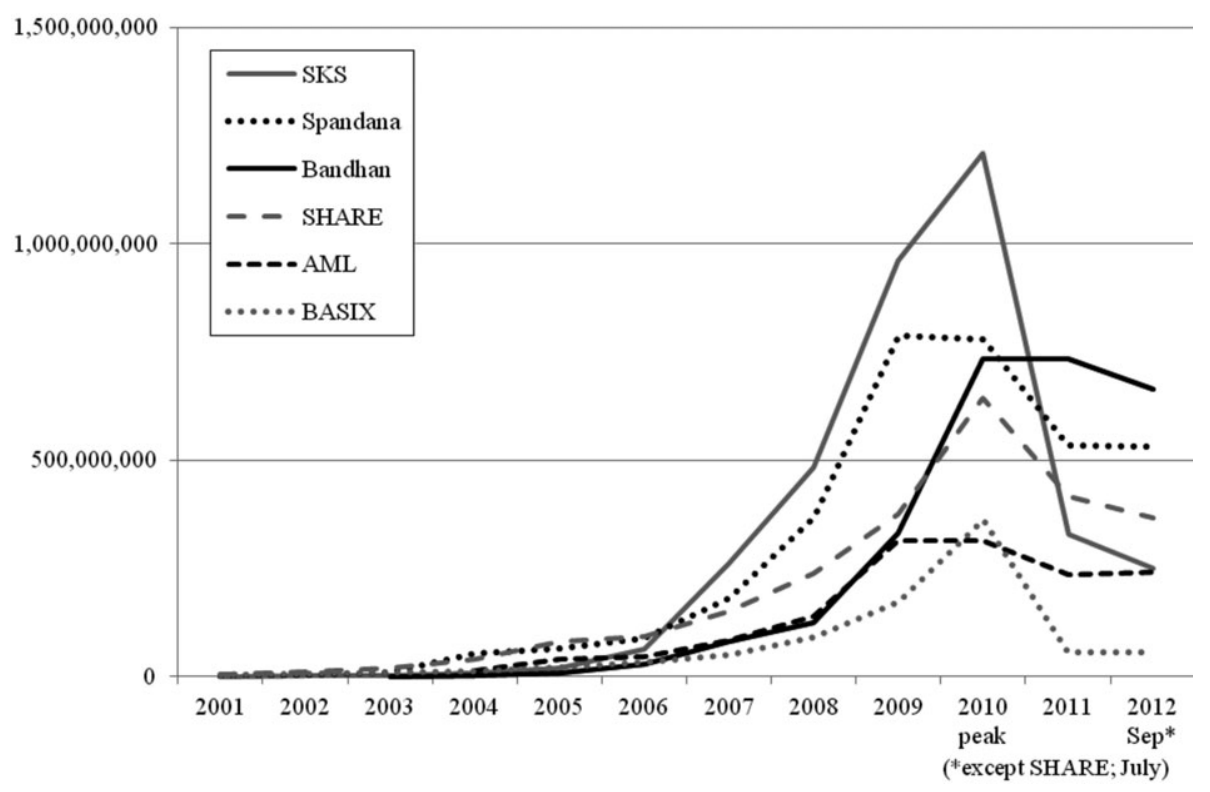

Figure 2. Gross loan portfolios (USD) of India's six largest MFIs (data: Mixmarket). ${ }^{24}$

microfinance industry's standard measure of loan performance. Before the crisis, PaR had been at less than $4 \%$ for seven years, even dropping to such utopian ${ }^{23}$ low levels as $0.14 \%$ of loans 90 days overdue in 2008 . By the end of 2010 , almost $25 \%$ of loans measured by volume were registered on the Mixmarket database as more than 30 days overdue ( $\mathrm{PaR}>30$ days), and nearly as many were 90 days late or more. By 2011, these figures had not improved, remaining at $24.2 \%$ and $23.5 \%$, respectively (Mixmarket, August 20, 2012).

${ }^{23}$ Arunachalam (2011, pp. 351-365) suggests that these levels could only have been attained using a combination of violence and intimidation against borrowers, and untruthful financial reporting. He cites a client stating: "Some collection agents were really rude after my wife committed suicide." They came and said, "If you cannot find means to repay, then you should send out your two beautiful daughters, and get them to earn money by other means (prostitution ....) and then repay to us" (Arunachalam, 2011, p. 362). He lists the following strategies for ensuring near-zero PaR: "Life/work obstruction; Threats; Verbal abuse; Following the client and pestering; Repossession and sale of property; Satyagraha [protest] outside client's house/place of work; Embarrassment strategy; Physically take over assets/documents as collateral; Physical intimidation" (Arunachalam, 2011, pp. 363-364). All done, of course, in the name of "empowering" the poor.
The PaR in 2011-2012 of those MFIs with more than a fifth of their lending in AP, reported by MFIN, was as high as $62.1 \%$ and $58.1 \%$ (for 30 and 90 days, respectively), indicating that the percentage of non-performing loans in AP itself may be near 100\%. Non-AP MFIs showed merely 3.3 and 2.9 PaR (30 and 90 days) (MFIN, 2012, pp. 37-38). Evidently, the Andhra microfinance market - the market on which most MFIs chose to focus until the crisis - has practically collapsed, while MFIs operating in other states are less affected. In 2011, across India, $8.02 \%$ of loans were permanently written off as "lost" (uncollectable), and the high PaR figures indicate that more loans are still to be written off.

As pertains to the impact of the industry's woes on borrowers, not only is the extent difficult to ascertain, but it is also unclear what criteria to use. The industry has sought to paint a picture of poor people losing their only access to much-needed finance (Legatum Ventures, 2012). Some sources report that MFIs continue with their "tactics

\footnotetext{
24 "Peak" value is highest quarterly figure ever reported to Mixmarket; all others except 2012 are year-end figures. Spandana's reported peak was in 2009.
} 


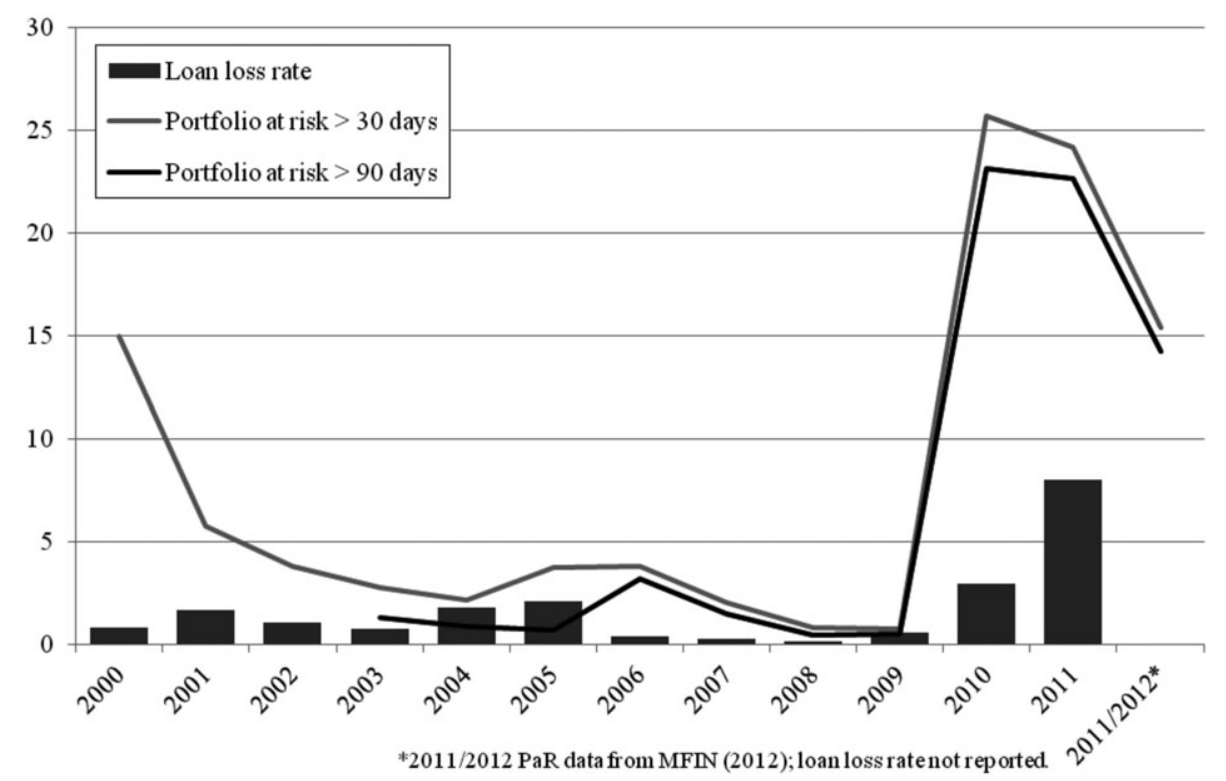

Figure 3. Portfolio quality \& loan loss rate (data: Mixmarket)

of intimidation," and that SHG poaching and interest rate deception have not subsided (see for instance Ramakrishnan, 2012), raising concerns that the root causes of the sector's (and the poor's) woes are not being addressed. But, for many borrowers, not repaying may in fact constitute a net redistributional gain which at least partly offsets the debts accrued and, in this way, the final outcome may even be relatively borrower-friendly.

As collateral damage of the MFIs' woes, SHGs appear to be suffering since banks are less keen to lend. As a banker put it, "We are not going to let SHG members repay their overdue loans to MFIs, using our money, much of which comprises of public deposits" (Arunachalam, 2011, p. 203).

It is not clear that the demise of the Andhra/Indian microfinance sector has harmed India's poor significantly, even if MFIs claimed continuously that borrowers were the real victims. As Nair (2011, p. 24) notes:

There is no evidence whatsoever that microcredit is a cheaper option for the poor. [.. .] That the large microfinance players in the market have not cared to reduce the interest rates closer to the bank rates over years of doing profitable business with the poor and realising phenomenal profitability margins, mostly through increased volumes, is evidence enough [. . .] that equity-financed MFIs cannot serve as pro-poor institutional alternatives.

In other words, the development of the Indian MFI sector since the late 1990s may have been a dead-end social policy, reversed only by the recent crisis.

On the supply side, the floodgates are momentarily shut. Indian MFIs have lost access to most of their main capital sources. Aware of the risks of non-repayment triggering insolvency, Indian banks are more worried about lending to MFIs than ever before. As in any financial crisis, bad news precipitates further trouble (Minsky, 1992), and MFIs' troubles created a credit squeeze. In terms of equity, investments into microfinance have effectively dried up, and unsurprisingly no IPOs have gone forward since SKS. The consultancy firm Intellecap organized an equity infusion by the IFC, a branch of the World Bank, for Bandhan in 2011, and took this as evidence that "investor interest is returning to the Microfinance space [...]. The worst is behind us - 
the confidence in the Microfinance model is gradually getting restored" (Intellecap, 2011). But the fact that the largest equity issue in 2011 was to the IFC, rather than a private investor, is telling. Private international investors are little interested, with only few exceptions like Crédit Agricole and Deutsche Bank picking up bargain shares in SKS at one-twentieth their peak value in July 2012; presumably, a speculative investment and not a capital infusion into Indian microfinance.

Following the recommendations of the Malegam Committee's report prepared under the auspices of the Reserve Bank of India (RBI), regulatory efforts in India have restarted, but made slow progress. The report, which was completed in January 2011, remarked that "Microfinance is an important plank in the agenda for financial inclusion. The future cannot be left entirely to the stating of good intention. It, therefore, calls for strong regulation" (Malegam, 2011, p. 54). It recommended measures including loan size caps, an interest rate ceiling of $24 \%$, limits on multiple lending, the creation of a credit information bureau, and a (vague) ban on "coercive methods of recovery," assigning regulatory responsibility to the RBI (Malegam, 2011, pp. 56-60). In May 2012, the Indian cabinet drafted a bill based on the Malegam recommendations, with some minor changes such as a $2 \%$ higher ceiling, but by January 2013 it had not passed Parliament's approval; its status remained "pending" (PRS Bill Track, 2013, as of January 2013). Thus, two years after the beginning of the massive Andhra crisis and more than seven years after the first major crisis, Indian microfinance still remains in the same regulatory vacuum which the AP government sought to fill with its hasty ordinance.

\section{Conclusion}

Making predictions is not the aim here, but the expectations spelled out by Arunachalam (2011, pp. 226-229) offer some disconcerting indications of the road ahead. He argues that, with Andhra, banks in India have received a second rude warning (after Krishna) and therefore MFIs will have to rely even more strongly on foreign equity capital than before. The sector may have to operate (at least temporarily) on reduced interest rates, making it less attractive for investors, and its equity reliance would benefit already-large MFIs, starving smaller ones, and potentially creating another race to the stock market if investors are willing to play ball. The defaults in AP will lead to more vigorous expansion in other states, possibly leading to similar patterns as in AP.

The analytical narrative presented in this article suggests that the proximate causes of the AP crisis were largely home-made, and the AP government's intervention was at most an enabling factor. Warning signs that Indian MFIs' spectacular growth and profitability rested on overwhelming indebtedness of clients — the industry's success in fact being merely a giant debt bubble - were amply present long before the crisis, but were blissfully ignored and later quietly forgotten. With stringent regulation still a notable absence, and a microfinance industry still in denial, there is little to suggest that the hubris underlying the Andhra microfinance crisis has not the potential to resurface again in India. Worse yet, as Milana and Ashta (2012, pp. 314-318) note, the Andhra crisis arose in the context of more widespread allegations of malpractice and a need for better regulation globally, indicating that it may not remain an isolated event. ${ }^{25}$ Rather, as Ghosh (2012, p. 10) warns:

The microfinance crisis in Andhra Pradesh provides almost a textbook example of what can go wrong in allowing the proliferation of relatively less regulated MFIs in a boom that occurs under the benign gaze of the government.

In the Andhra boom, the music played until a sufficient number of suicides forced the government to intervene. But the fundamental causes of the crisis lay with India's historical tradition of (ab)using debt as a tool of

\footnotetext{
${ }^{25}$ This crisis already followed on the heels of smaller crises in Bolivia, Bosnia-Herzegovina, Pakistan, Morocco, and Nicaragua (Chen et al., 2010; Rhyne, 2001).
} 
social policy. If there is one key lesson to be learnt from this more contextualized account of the Andhra Pradesh microfinance crisis, it is that deeper-seated social problems cannot be resolved with an infusion of debt, and that industries built on that premise are bound to fail eventually. The persistent social crisis of India's poor (particularly in Andhra Pradesh), which policy-makers sought to address through credit via SHGs and MFIs, made borrowers increasingly dependent on debt for survival. MFIs competed with SHGs and each other to feed that debt dependency. The reckless and unregulated growth of the Indian microfinance industry, concentrated on one state, created a drive for profitability at all costs (including human costs), and the industry's unwillingness to heed any warnings, even from well-intentioned insiders, sealed its fate.

Thus, the commonly accepted story of a nefarious Andhra government preying on a healthy microfinance sector is dubious, at best. Without a doubt, the government regulated clumsily, as could be expected from provincial authorities intervening in international financial circuits. Yet there is no question about its intervention upon sustained reports of violence, abuses, and widespread overindebtedness being necessary. The AP ordinance may be seen as a late and blundering attempt by a regional legislator to play the political role of balancing relations between economic agents. For a democratic government it was impossible not to intervene upon sustained reports of its poorest citizens being exploited, abused, and driven to suicide by organizations purporting to help them. However, in intervening, the AP legislature offered itself as a useful culprit to the microfinance industry, which — perhaps even unbeknownst to itself — had reached the limits of its unsustainable expansion.

\section{References}

Acharya N. 2010. After SKS success, more microfinance public issues on the horizon. Business Standard, Kolkata, August 31, 2010. Available at: http://www.business-standard.com/india/ news/after-sks-success-more-microfinance-public-issues-arethehorizon/406417/.

Aiyar SSA, Narayan D, Raju K. 2007. Empowerment through self-help groups: Andhra Pradesh shows the way in India. In Ending Poverty in South Asia: Ideas That Work, Glinskaya EE, Narayan D (eds). The International Bank for Reconstruction and Development/The World Bank: Washington DC; pp. 104-135.

Arunachalam RS. 2011. The Journey of Indian Micro-Finance: Lessons for the Future. Aapti Publications: Chennai.

Ashta A, Bush M. 2008. Ethical issues of NGO principals in sustainability, outreach and impact of microfinace: Lessons in governance from the Banco Compartamos IPO. Management Online Review, November 2009, pp. 1-18.

Ashta A, Hudon M. 2012. The Compartamos microfinance IPO: Mission conflicts in hybrid institutions with diverse shareholding. Strategic Change 21(7\&8): 331-341.

Ashta A, Khan S, Otto PE. 2011. Does microfinance cause or reduce suicides? Policy recommendations for reducing borrower stress. March 3, 2011. Available at: http://ssrn.com/ abstract $=1715442$.

Bamzai S. 2010. In 13 years, we've never been accused of contributing to suicide: Vikram Akula. India Today, Mumbai, November 4, 2010. Available at: http://indiatoday.intoday.in/ story/in-13-years-weve-never-been-accused-of-contributingto-suicide-vikram-akula/1/118955.html.

Bellman E. 2010. Microlenders make millions with SKS IPO. India Real Time. The Wall Street Journal, New York City, July 28, 2010. Available at: http://blogs.wsj.com/ indiarealtime/2010/07/28/microlenders-make-millions-with-sks-ipo/.

Bhoir A. 2008. Big microfinance firms taking over clients of smaller players. Livemint \& The Wall Street Journal, Delhi, November 25, 2008. Available at: http://www.livemint. com/2008/11/25003211/Big-microfinance-firms-taking. html.

Burgess R, Pande R. 2003. Do rural banks matter? Evidence from the Indian social banking experiment. DEDPS Discussion Paper, No. 40.

Chadha S. 2009. The truth about private equity and microfinance. Interview: Sumir Chadha, Managing Director, Sequoia Capital India. Microfinance Insights. Intellecap, Hyderabad. 
Available at: http://intellecap.com/assets/1/MFInsights_july 09_Chadha.pdf.

Champatiray AK, Agarwal P, Sadhu S. 2012. Map of microfinance distribution in India. Finance ICfM (ed.). IFMR Centre for Micro Finance, Chennai. Available at: http://www.centre-formicrofinance.org/wp-content/uploads/2012/02/Updated_Final_ Report_Map_of_Microfinance_Report_CMF_June27.pdf.

Chen G, Rasmussen S, Reille X. 2010. Growth and vulnerabilities in microfinance. CGAP Focus Note No. 61 (February).

Chowdri S. 2011. Consequences of over-indebtedness: Lessons from India (originally published in June 2009). Center for Financial Inclusion Blog, ACCION International, September 6, 2011. Available at: http://centerforfinancialinclusionblog. wordpress.com/2011/09/06/consequences-of-overindebtednesslessons-from-india/.

CIA World Factbook. 2011. CIA World Factbook: India: Economy. CIA, Washington DC. Available at: https://www. cia.gov/library/publications/the-world-factbook/geos/in.html.

Damodaran A. 2011. The data page. Useful Data Sets, New York City. Available at: http://people.stern.nyu.edu/ adamodar/New_Home_Page/data.html.

Datta R. 2003. From development to empowerment: The SelfEmployed Women's Association in India. International Journal of Politics, Culture and Society 16(3): 351-368.

David R. 2010. Threat of microfinance defaults rise in India as SKS plans IPO. Bloomberg, New York City, June 14, 2010. Available at: http://www.bloomberg.com/news/2010-06-14/ india-microfinance-evokes-risk-of-subprime-in-the-east-assks-prepares-ipo.html.

Fernandez AP. 2009. Is micro finance leading to a macro mess? MYRADA: Rural Management Systems Series 55(2).

Ghate P. 2006. Microfinance in India: A state of the sector report. Microfinance India, New Delhi. Available at: http:// www.microfinanceindia.org/download_reports/state_of_the_ sector_06.pdf.

Ghate P. 2007a. Consumer protection in Indian microfinance: Lessons from Andhra Pradesh and the microfinance bill. Economic and Political Weekly 42(13): 1176-1184.

Ghate P. 2007b. Learning from the Andhra Pradesh crisis. In What's Wrong with Microfinance?, Dichter T, Harper M (eds).
Immediate Technology Publications: Bourton on Dunsmore; pp. 163-176.

Ghosh J. 2012. Microfinance and the challenge of financial inclusion for development. Paper for presentation at the Annual Conference of the Central Bank of Argentina, October 1-2, 2012. Available at: http://www.bcra.gov.ar/pdfs/eventos/ JMB_2012_Ghosh.pdf.

Gokhale K. 2009a. As microfinance grows in India, so do its rivals. The Wall Street Journal, New York City, December 15, 2009. Available at: http://online.wsj.com/article/SB126055 117322287513.html.

Gokhale K. 2009b. In microlending, group borrowing leads to pressure. The Wall Street Journal, New York City, August 13, 2009. Available at: http://online.wsj.com/article/SB12500823 2217325553.html.

Government of Andhra Pradesh. 2010. An Ordinance to protect the women Self Help Groups from exploitation by the Micro Finance Institutions in the State of Andhra Pradesh and for the matters connected therewith or incidental thereto [Andhra Pradesh Micro Finance Institutions (regulation of money lending) Ordinance, 2010]. MEPMA, Hyderabad. Available at: http://www.apmepma.gov.in/downloads/Bank\%20Link ages/MFI_Ordinance.pdf.

Harper M, Iyer L, Rosser J. 2011. Whose Sustainability Counts? BASIX's Long March from Microfinance to Livelihoods. Kumarian Press: Sterling, VA.

India Microfinance. 2009. SKS Microfinance and ICICI bank conclude securitisation deal. India Microfinance Business News, February 19, 2009. Available at: http://indiamicrofinance. $\mathrm{com} /$ sks-microfinance-icici-bank-conclude-securitisationdeal.html.

India Microfinance. 2010. SKS Microfinance IPO gets George Soros as an investor. India Microfinance, July 23, 2010. Available at: http://indiamicrofinance.com/sks-microfinanceipo-george-soros-investor.html.

Intellecap. 2007. Inverting the pyramid: The changing face of Indian microfinance. Intellecap, Hyderabad, October. Available at: http://www.microfinancegateway.org/gm/document1.9.26137/24.pdf.

Intellecap. 2010. Indian microfinance crisis of 2010: Turf war or a battle of intentions? White Paper. Intellecap, Hyderabad, 
October. Available at: http://beyondprofit.com/Intellecap $\% 20$ Microfinance\%20White\%20Paper\%20\%28Oct\%202010\% 29.pdf.

Intellecap. 2011. Investor interest returning to Indian microfinance space. Press release. Intellecap, Hyderabad. Available at: http://t.co/hwhVYcu.

Johnson D, Meka S. 2010. Access to finance in Andhra Pradesh. Institute for Financial Management and Research Centre for Micro Finance, October. Available at: http://www. microfinancegateway.org/p/site/m/template.rc/1.9.48511/.

Kohli A. 2012. Poverty Amid Plenty in the New India. Cambridge University Press: Cambridge.

Kumar V, Rozas D. 2010. Exclusive: SKS Microfinance journey to IPO - An inside story. Microfinance Focus. Microfinance News, May 17, 2010. Available at: http://www.microfinance focus.com/news/2010/05/17/exclusive-sks-microfinance-journeyto-ipo-an-inside-story/.

Legatum Ventures. 2011. Microfinance in India: A crisis at the bottom of the pyramid. Legatum Ventures, Dubai, May. Available at: http://www.legatum.org/attachments/ MicrofinanceCrisis.pdf.

Legatum Ventures. 2012. Indian microfinance: Looking beyond the AP Act and its devastating impact on the poor. Legatum Ventures, Dubai, March. Available at: http://www.legatum. $\mathrm{com} /$ newsdisplay.aspx?id $=6440$.

Maggio C. 2010. Microcapital brief: SKS Microfinance Limited, Microfinance Institution (MFI) in India, files to raise $\$ 250 \mathrm{~m}$ in Initial Public Offering (IPO). MicroCapital, Boston, MA, March 29, 2010. Available at: http://www.microcapital.org/ microcapital-brief-sks-microfinance-limited-microfinance-institution-mfi-in-india-files-to-raise-250m-in-initial-publicoffering-ipo/.

Malegam YH. 2011. Report of the Sub-Committee of the Central Board of Directors of the Reserve Bank of India to Study Issues and Concerns in the MFI Sector. Reserve Bank of India, Mumbai, January 19, 2011. Available at: http://www. rbi.org.in/scripts/PublicationReportDetails.aspx?UrlPage= $\& \mathrm{ID}=608$.

MFIN. 2012. The MicroScape November 2012. Microfinance Institutions Network, Gurgaon.

Milana C, Ashta A. 2012. Developing microfinance: A survey of the literature. Strategic Change 21(7-8): 299-330.
Minsky HP. 1992. The financial instability hypothesis. The Jerome Levy Economics Institute Working Papers, No. 74.

Mixmarket. 2008. 2008 MIX Global 100 Composite: Rankings of Microfinance Institutions. Report from the Microfinance Information Exchange, Inc. (MIX), Washington DC. Available at: http://www.themix.org/sites/default/files/2008\%20 MIX\%20Global\%20100\%20updated\%20March\%202009. pdf.

Morris M. 2011. Investigating India's microcredit crisis. $B B C$ World Agenda. BBC, London, January 26, 2011. Available at: http://www.bbc.co.uk/worldservice/worldagenda/2011/01/ 110126_worldagenda_india_microcredit.shtml.

NABARD. 2012. Status of microfinance in India 2011-2012. National Bank for Agriculture and Rural Development, Micro Credit Innovations Department, Mumbai. Available at: http:// www.nabard.org/pdf/MF\%20book\%20-\%20full.pdf.

Nagaraju J. 2010. MFI agents 'forcing' debtors to commit suicide: Study. The Times of India, Mumbai, October 20, 2010. Available at: http://articles.timesofindia.indiatimes. com/2010-10-20/india/28247030_1_mfi-agents-loanamount-elimination-of-rural-poverty.

Nair A. 2005. Sustainability of microfinance self help groups in India: Would federating help? World Bank Policy Research Working Paper No. 3516. The World Bank, Washington DC. Available at: http://www-wds.worldbank.org/servlet/ WDSContentServer/WDSP/IB/2005/03/06/000090341_20 050306103912/Rendered/PDF/wps3516.pdf.

Nair TS. 2011. Microfinance: Lessons from a crisis. Economic \& Political Weekly xlvi(6): 23-26.

Nath S. 2009. At the crossroads. Forbes India Magazine, Mumbai, September 25, 2009. Available at: http://business. in.com/article/boardroom/at-the-crossroads/4262/0.

Nayar L, Tata M, Mitra D. 2010. Is it micro usury? Outlook India, New Delhi, October 18, 2010. Available at: http:// www.outlookindia.com/article.aspx?267394.

NDTV Profit. 2010. MFI Ordinance effect: Borrowers in AP stop repaying loans. NDTV Profit, New Delhi, October 19, 2010. Available at: http://profit.ndtv.com/news/show/ mfi-ordinance-effect-borrowers-in-ap-stop-repaying-loans110191.

Parameshwar D, Aggarwal N, Zanchi R, Shankar SS. 2010. Indian MFIs: Growth for old and new institutions alike. 
MicroBanking Bulletin, September 20, 2010. Available at: http://www.themix.org/sites/default/files/MBB\%2020\%20 -\%20Indian \%20MFIs\% 20-\%20 Growth \%20 for \% 20 Old\%20and\%20New\%20Institutions\%20Alike.pdf.

PRS Bill Track. 2013. The Micro Finance Institutions (Development and Regulation) Bill, 2012. PRS Legislative Research. Available at: http://www.prsindia.org/billtrack/the-microfinance-institutions-development-and-regulation-bill-2012$2348 /$.

Rai V. 2010. India's microfinance crisis is a battle to monopolize the poor. Harvard Business Review Blog Network, Cambridge, MA, November 4, 2010. Available at: http://blogs.hbr.org/ cs/2010/11/indias_microfinance_crisis_is.html.

Rajshekhar M, Grenny J. 2010. SKS IPO proceeds will go to non-profit work. The Economic Times, Mumbai, August 13, 2010. Available at: http://articles.economictimes.indiatimes. com/2010-08-13/news/27579870_1_unitus-equity-fundmicrofinance-organisations-profit.

Ramakrishnan T. 2012. Collectors keeping watch on MFI operations. The Hindu, Chennai, April 19, 2012. Available at: http://www.thehindu.com/news/cities/chennai/article3329 351.ece.

Reddy KR, Reddy T, Prahallada S. Year unknown. SHG-bank linkage programme: A study on loan default and recovery. APMAS Studies, APMAS. Available at: http://www.apmas. org/pdf/SHG-\%20Bank\%20Linkage\%20-\%20Study\%20 on\%20Loan\%20Default\%20and\%20Recovery.pdf.

Rediff Business. 2004. Banks take the hint, to step up farm loans. Rediff Business, Mumbai, May 28, 2004. Available at: http://inhome.rediff.com/money/2004/may/28spec.htm.

Reserve Bank of India. 2011. FAQs: Priority sector lending. Available at: http://www.rbi.org.in/scripts/faqview.aspx?id $=8$.

Rhyne E. 2001. Commercialization and crisis in Bolivian microfinance. Microenterprise Best Practices. Development Alternatives, Inc., Bethesda, MD. Available at: http://www. microfinancegateway.org/gm/document-1.9.28329/28001_ file_commercialization_and_crisis_4.pdf.

Rozas D. 2009. Is there a microfinance bubble in South India? Microfinance Focus. Microfinance News, November 17, 2009. Available at: http://www.microfinancefocus.com/news/2009/ 11/17/opinion-microfinance-bubble-south-india/.
Rozas D. 2012. Repairing a tarnished image: A plea for transparency in Indian microfinance. Microfinance Focus. Microfinance News, March 28, 2012. Available at: http://www. microfinancefocus.com/mffnews/repairing-tarnished-imageplea-transparency-indian-microfinance.

SERP. 2010. Exclusive: 54 microfinance-related suicides in AP, says SERP report. Microfinance Focus. Microfinance News, October 25, 2010. Available at: http://www.microfinancefo cus. com/content/exclusive-54-microfinance-related-suicides -ap-says-serp-report.

Shah M, Rao R, Shankar PSV. 2007. Rural credit in 20th century India: An overview of history and perspectives. Economic and Political Weekly 42(15): 1351-1364.

Shankaran S. 2010. Akula defends SKS, MFI industry. Livemint \& The Wall Street Journal, Delhi, November 17, 2010. Available at: http://www.livemint.com/2010/11/16224132/ Akula-defends-SKS-MFI-industr.html.

Sharma S. 2006. Death by microcredit. The Times of India, Mumbai, September 16, 2006. Available at: http://articles. timesofindia.indiatimes.com/2006-09-16/edit-page/27819 404_1_erring-mfis-suicides-loan-recovery-practices.

Shridhar G. 2010. AP's microfinance institutions admit to charging up to $60.5 \%$. The Hindu, October 30, 2010. Available at: http://www.thehindubusinessline.com/2010/10/30/ stories/2010103052310100.htm.

Shylendra HS. 2006. Microfinance Institutions in Andhra Pradesh: Crisis and Diagnosis. Economic and Political Weekly, May 20, 2006: 1959-1963.

SIDBI. 2011. Study on Interest Rates and Costs of Microfinance Institutions. Small Industries Development Bank of India, Lucknow. Available at: http://www.sidbi.in/micro/ IMAGES/Final_SIDBI_Report.pdf.

Sify News. 2010. Protests against finance firms as two more commit suicide. Sify News, Chennai, October 11, 2010. Available at: http://www.sify.com/news/protests-againstfinance-firms-as-two-more-commit-suicide-news-nationalkklr4cibhbj.html.

Srinivasan N. 2009. Microfinance India: State of the Sector Report 2009. SAGE Publications India, New Delhi.

Srinivasan N. 2010. Crisis by Invitation. CGAP Microfinance Blog, November 19, 2010. Available at: http://www. mftransparency.org/crisis-by-invitation/. 
Sriram MS. 2010. What is Wrong With Indian Microfinance. Forbes India, May 5, 2010. Available at: http://business. in.com/article/special/what-is-wrong-with-indian-micro finance/12962/0.

Strom S, Bajaj V. 2010. Rich I.P.O. Brings Controversy to SKS Microfinance. The New York Times, New York City, July 29, 2010. Available at: http://www.nytimes.com/2010/07/30/ business $/ 30$ micro.html?pagewanted $=1$.

Sudhir U. 2010. Put in place loan collection mechanism: AP court. NDTV Profit, New Delhi, October 20, 2010. Available at: http://profit.ndtv.com/news/show/put-in-place-loan-collec tion-mechanism-ap-court-110667.

Swibe M. 2007. The 50 Top Microfinance Institutions. Forbes, New York City, December 20, 2007. Available at: http://www. forbes.com/2007/12/20/microfinance-philanthropy-creditbiz-cz_ms_1220microfinance_table.html.

Taylor M. 2011. 'Freedom from Poverty is Not for Free': Rural Development and the Microfinance Crisis in Andhra Pradesh, India. Journal of Agrarian Change 11(4): 484-504.

The Economic Times. 2010a. SKS Microfinance debuts at 11\% premium. The Economic Times, Mumbai, August 17, 2010. Available at: http://articles.economictimes.indiatimes. com/2010-08-17/news/27599524_1_sks-shares-listing-gainssks-microfinance.

The Economic Times. 2010b. 30 commit suicide in 45 days to escape microfinance agents. The Economic Times, Mumbai, October 15, 2010. Available at: http://articles.economictimes. indiatimes.com/2010-10-15/news/27621807_1_mfis-suicidecredit-flow.

The Economist. 2000. The state that would reform India. The Economist, London, August 31, 2000. Available at: http:// www.economist.com/node/354212.

The Hindu. 2010. Rising suicides force AP ordinance to check microfinance firms. The Hindu, Chennai, October 14, 2010. Available at: http://www.thehindu.com/business/article8305 11.ece.

The Hindu Business Line. 2010. Microfinance institutions cut interest to $24 \%$ in AP. The Hindu Business Line, Chennai,
November 4, 2010. Available at: http://www.thehindubusinessline.com/todays-paper/article1008602.ece? $r$ ef=archive.

The Hindu Business Line. 2011. Microfinance sector may decline $20-40 \%$ this year. The Hindu Business Line, Chennai, September 13, 2011. Available at: http://www.thehindubusi nessline.com/industry-and-economy/banking/article 24500 70.ece.

Times of India. 2010a. Agents kidnap girl to punish mother for loan default. The Times of India, Mumbai, October 13, 2010. Available at: http://articles.timesofindia.indiatimes.com/201010-13/india/28229879_1_agents-loan-girl\#ixzz12C5V6J8n.

Times of India. 2010b. Caught in loan co trap, farmer kills self in Andhra. The Times of India, Mumbai, October 14, 2010. Available at: http://articles.timesofindia.indiatimes.com/201010-14/india/28255877_1_mfi-loan-instalments-loanrepayment.

Times of India. 2010c. Tormented by MFI, another woman kills self. The Times of India, Mumbai, September 29, 2010. Available at: http://articles.timesofindia.indiatimes.com/201009-29/hyderabad/28235452_1_yemmiganur-town-loandaughters.

Turnell S. 2005. The Rise and Fall of Cooperative Credit in Colonial Burma. Macquarie University, Department of Economics Research Papers 0509.

Wolff HW. 1910. People's Banks: A Record of Social and Economic Success. P. S. King \& Son: London.

World Bank. 2011. India - Andhra Pradesh Rural Poverty Reduction Project : P071272 - Implementation Status Results Report : Sequence 16. Washington, DC: World Bank. Available at: http://documents.worldbank.org/curated/en/2011/ 10/15185804/india-andhra-pradesh-rural-poverty-reductionproject-p071272-implementation-status-results-reportsequence-16

Wright GAN, Sharma MK. 2010. The Andhra Pradesh Crisis: Three Dress Rehearsals ... and then the Full Drama. MicroSave India Focus Note 55 (December 2010).

Young S. 2010. Gender, Mobility and the Financialisation of Development. Geopolitics 15(3): 606-627. 


\section{BIOGRAPHICAL NOTE}

Philip Mader studied Economics and Development Studies at Sussex and Cambridge, earning his Doctorate at the University of Cologne with a thesis on the political economy of microfinance's rise and crises, based on fieldwork in Andhra Pradesh. He currently holds a postdoctoral research position at the Max Planck Institute for the Study of Societies.
Corresponding author:

Philip Mader

Max Planck Institute for the Study of Societies

Paulstr. 3

50676 Cologne

Germany

e-mail: mader@mpifg.de 